\title{
The Leopard DVD
}

\author{
By Jan Uhde
}

\section{Fall 2004 Issue of KINEMA}

In 1963, Luchino Visconti completed his Italian Risorgimento epic The Leopard (Il gattopardo, 1963) - one of the best Italian films ever made and a classic of world cinema. In it, the director conjures an era of aristocratic elegance and charm, his own world in fact, being swept away by the energetic and unscrupulous upstarts of the rising bourgeoisie - "the jackals and the sheep" - opportunistically surfing the waves of Garibaldi's popular uprising. This successful transformation into film of the spirit of Giuseppe Tomasi Di Lampedusa's outstanding novel was made possible by the participation of several exceptional artists: the scriptwriter Suso Cecchi D'Amico, without whose genius neither The Leopard nor much of the best post-war Italian cinema would exist; the cinematographer Giuseppe Rotunno; the composer Nino Rota; the costume designer Piero Tosi; the resplendent Claudia Cardinale, and, last but not least, the experienced Hollywood star Burt Lancaster whose magnificent presence as the aging Prince of Salina infused the film with an almost palpable atmosphere of nineteenth century Sicily. Although the film's production company, Titanus, was practically bankrupted by Visconti's super-expensive extravaganza, the producer Goffredo Lombardo decided that this risk had to be taken for the sake of an idea he believed in.

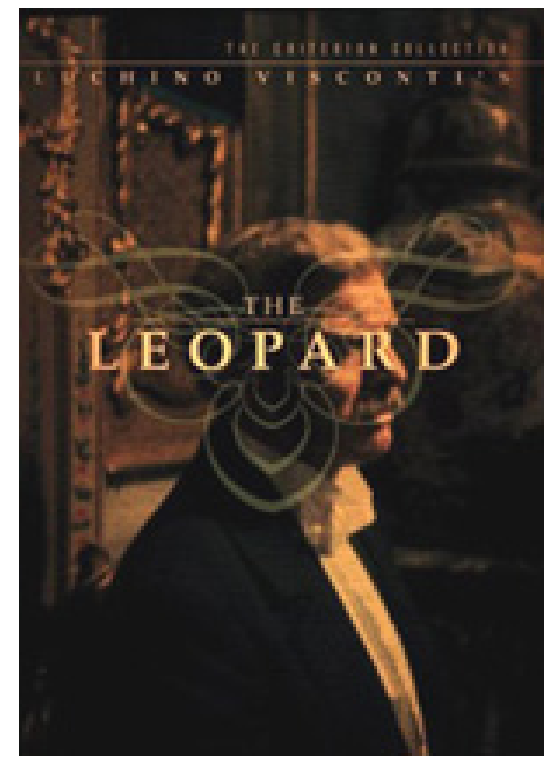

Figure 1: THE LEOPARD DVD ๆ Dir. Luchino Visconti, Italy 1963 ฯ 3-disc set, NTSC, Reg. 1 ฯ Criterion Collection, 2004 ฯ USD 49.95. Discounts

For decades, The Leopard remained in the vault, slowly disappearing from memory, apparently sharing the fate of Visconti's vanishing "leopards." But now it is back - with a roar - in Criterion Collection's 3-disc special DVD edition, released in June 2004. The collection includes a high-definition transfer of the feature with restored image and sound (in the original Super Technirama 2.21:1, $187 \mathrm{~min}$ ) supervised by Rotunno, with an optional audio commentary by Peter Cowie (Disc 1). Disc 2 contains the 60 -minute documentary A Dying Breed: The Making of The Leopard, comprising interviews with the film's collaborators including Suso Cecchi D'Amico, Claudia Cardinale and Sydney Pollack. In addition, it contains separate interviews with the film's producer Lombardo and with Millicent Marcus, Professor of the University of Pennsylvania; theatrical trailers, stills and production photos. Disc 3 contains the English-language US version of the film (2.35:1, $161 \mathrm{~min})$. A booklet by the American scholar and writer Michael Wood completes the set.

In September 2004, a PAL-Region 2 DVD of The Leopard was released in the UK (178 min, single disc) by BFI Video Publishing. Included is the main feature's restored original version, commentary and interview 
extracts with Claudia Cardinale, theatrical trailer and a biography of Visconti.

In France, 2-disc DVD Collector's Edition of The Leopard is also available (Le Guépard, Titanus-Pathé, November 2003, PAL-Region 2); some sources claim the film's length to be 205min. The French set includes a trailer, a documentary on the film's restoration, interviews with Visconti, Producer Lombardo, Claudia Cardinale and Alain Delon, plus photos and TV newsreel clips of the period.

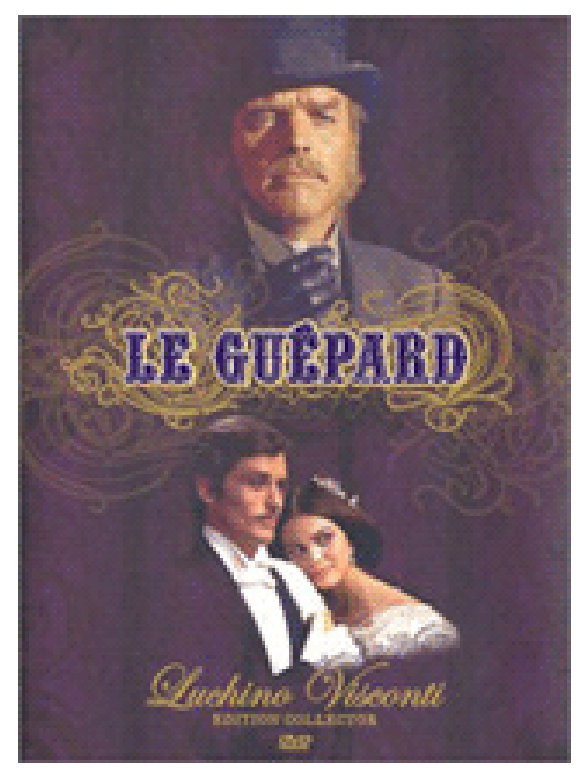

Figure 2:

\section{Author Information}

Jan UHDE is Professor Emer. (Film Studies) at the University of Waterloo, Ontario, Canada. Born in Brno, Czech Republic. Graduated (MA) from the Faculty of Arts, Masaryk University, Brno; PhD received at the University of Waterloo, Ontario, Canada. He taught at the University of Waterloo (1970-2012) where he founded a General and Honours BA program in Film Studies at the Department of Fine Arts.

Publications: Latent Images: Film in Singapore Second edition, with Yvonne Ng Uhde (Ridge Books, National University Press of Singapore, 2010); Latent Images: Film in Singapore, with Yvonne Ng Uhde (Oxford University Press, 2000); Latent Images: Film in Singapore CD-ROM (2003, co-author); Vision and Persistence: Twenty Years of the Ontario Film Institute (University of Waterloo Press, 1990) and Ontario Film Institute Programming Activities Index 1969-1989 (Toronto: Ontario Science Centre, 1990). He co-edited the Place in Space: Human Culture in Landscape (Proceedings from the Second International Conference of the Working Group "Culture and Landscape" of the International Association of Landscape Ecology, Pudoc Scientific Publishers, Wageningen, Holland, 1993). Jan Uhde has published articles and reviews in several countries (including Canada, USA, Germany, Italy), participated in international juries at film festivals and presented papers at international conferences in North America and Europe. In 1998/99, he was a visiting researcher at the School for Film and Media Studies, Ngee Ann Polytechnic, Singapore.

His professional and research interests focus on Singapore cinema; the identification and distancing mechanisms of the film viewer; the non-authored modifications and manipulation of films; and specific aspects of film history, including the Central European cinema.

He founded KINEMA in 1993. 